\title{
Quaternaire
}

Revue de l'Association française pour l'étude du

Quaternaire

vol. 18/2 | 2007

Volume 18 Numéro 2

\section{Electron Spin resonance (ESR) dating of some European Late Lower Pleistocene sites}

Datation par résonance de spin électronique (ESR) de quelques sites pléistocène

inférieur d'Europe

Jean-Jacques Bahain, Christophe Falguères, Pierre Voinchet, Matthieu Duval, Jean-Michel Dolo, Jackie Despriée, Tristan Garcia and Hélène Tissoux

\section{(2) OpenEdition}

\section{Journals}

Electronic version

URL: http://journals.openedition.org/quaternaire/1048

DOI: 10.4000/quaternaire.1048

ISSN: 1965-0795

\section{Publisher}

Association française pour l'étude du quaternaire

\section{Printed version}

Date of publication: 1 June 2007

Number of pages: 175-186

ISSN: 1142-2904

\section{Electronic reference}

Jean-Jacques Bahain, Christophe Falguères, Pierre Voinchet, Matthieu Duval, Jean-Michel Dolo, Jackie Despriée, Tristan Garcia and Hélène Tissoux, «Electron Spin resonance (ESR) dating of some European Late Lower Pleistocene sites », Quaternaire [Online], vol. 18/2 | 2007, Online since 01 June 2010, connection on 03 March 2020. URL : http://journals.openedition.org/quaternaire/1048 ; DOI : 10.4000/quaternaire.1048 


\title{
ELECTRON SPIN RESONANCE (ESR) DATING OF SOME EUROPEAN LATE LOWER PLEISTOCENE SITES
}

\author{
Jean-Jacques BAHAIN ${ }^{1}$, Christophe FALGUÈRES ${ }^{1}$, Pierre VOINCHET ${ }^{1}$, \\ Matthieu DUVAL ${ }^{1}$, Jean-Michel DOLO ${ }^{2}$, Jackie DESPRIÉE ${ }^{1}$, \\ Tristan GARCIA $^{1 \& 2} \&$ Hélène TISSOUX ${ }^{1 \& 3}$
}

\begin{abstract}
In Western Europe, most of the oldest prehistoric sites (ranging from 2 Ma to $500 \mathrm{ka}$ ) are associated with clastic or carbonated karstic environments. Here, the electron spin resonance (ESR) dating method is often the only one method permitting to place these localities in the global Quaternary framework, which is mainly based on marine isotopic data and palaeomagnetical record. ESR can be applied on different materials frequently recovered in archaeological sites such as tooth enamel, quartz grains or carbonates. In this paper, we present the results, which have been obtained for more than ten years on different archaeological sites of the late Lower Pleistocene or the early Middle Pleistocene, which are crucial for the understanding of the first human settlements of Europe: Pont-de-Lavaud and Grâce-Autoroute (France), Atapuerca Gran Dolina (Spain), Monte Poggiolo and Isernia La Pineta (Italy). Wherever possible, the ESR results were compared with those of independent dating methods, including ${ }^{39} \mathrm{Ar} /{ }^{40} \mathrm{Ar}$, palaeomagnetism and biostratigraphy. In some cases, the ESR method applied on bleached quartz extracted from fluvial sediments and the ESR/U-series method on tooth enamel were the only available methods to provide geochronological data.
\end{abstract}

Key-words: Geochronology, Pleistocene, ESR method, fluvial quartz, tooth enamel.

\section{RÉSUMÉ}

DATATION PAR RÉSONANCE DE SPIN ÉLECTRONIQUE (ESR) DE QUELQUES SITES PLÉISTOCÈNE INFÉRIEUR D’EUROPE

En Europe occidentale, la plupart des sites préhistoriques les plus anciens (compris entre 2 millions d'années et 500000 ans) se trouvent en contexte détritique ou carbonaté karstique. Dans de tels cas, la méthode de datation par résonance de spin électronique (ESR) est souvent la seule méthode géochronologique permettant de replacer ces gisements dans le cadre chronologique du Quaternaire établi notamment à partir des données isotopiques marines et du paléomagnétisme. Cette méthode a également pour avantage d'être applicable sur plusieurs types de supports que l'on retrouve fréquemment sur les sites préhistoriques : émail dentaire, grains de quartz ou carbonates. Nous présentons dans ce travail les résultats obtenus depuis une dizaine d'années sur des sites préhistoriques de la fin du Pléistocène inférieur ou du début du Pléistocène moyen, sites importants pour la compréhension des premiers peuplements de l'Europe : Pont-de-Lavaud et Grâce-Autoroute (France), Atapuerca Gran Dolina (Espagne), Monte Poggiolo et Isernia La Pineta (Italie). Chaque fois que cela était possible, les résultats ESR ont été comparés avec ceux obtenus par des méthodes indépendantes, comme le paléomagnétisme, la biostratigraphie ou la méthode ${ }^{39} \mathrm{Ar} /{ }^{40} \mathrm{Ar}$ mais, dans certains cas, les méthodes ESR sur grains de quartz extraits de sédiments fluviatiles et ESR/U-Th sur émail dentaire se sont révélées comme les seules méthodes utilisables pour fournir des points de repère chronologiques.

Mots-clés : Géochronologie, Pléistocène, méthode ESR, quartz fluviatile, émail dentaire.

\section{1 - INTRODUCTION}

Since the end of the 1970s, the Electron Spin Resonance (ESR) dating method has frequently been used to provide geochronological data on Middle Pleistocene sites (for details and reviews see Grün, 1989; Ikeya, 1993; Rink, 1997; Falguères \& Bahain, 2002). Methodological developments in the last few years now allow the successful application of this method for this time frame ages, mainly on two kinds of material, tooth enamel and bleached quartz extracted from sediments (Bahain et al., 2002).

After a brief survey of the general basis of ESR method and its application on tooth enamel and bleached quartz, we present selected representative results which were obtained by the Geochronology Unit of the Department of Prehistory, National Museum of Natural History, Paris, France, on the dating of suspected Lower Pleistocene sites. The ESR data will be discussed in the context of results provided by

\footnotetext{
${ }^{I}$ Département de Préhistoire du Muséum national d'histoire naturelle, USM 204, UMR 5198 du CNRS, 1 rue René Panhard 75013 Paris, France. E-mail: bahain@mnhn.fr

${ }^{2}$ Laboratoire National Henri Becquerel, CEA/Saclay, 91191 Gif-sur-Yvette, France.

${ }^{3}$ Department of Applied Physics, Okayama University of Science 1-1 Ridai, Okayama, 700-0005, Japan.
} 
independent methods such as ${ }^{39} \mathrm{Ar}^{-40} \mathrm{Ar}$ dating magnetostratigraphy and biostratigraphy.

\section{2 - ESR DATING METHOD}

ESR dating is based on the time dependent accumulation of trapped electrons in mineral defects proportionally to the natural radioactivity. Rocks and sediments contain radioactive elements, mainly potassium and the isotopes of the uranium and thorium chains. The natural radioactive decay of these nuclides is accompanied by the emission of ionizing rays. Hence, in the nature, a mineral is submitted to permanent irradiation because of the presence of such radioactive elements in the mineral itself as well as in its environment.

The intensity of an ESR signal is proportional to the radiation dose (= palaeodose), $\mathrm{D}_{\mathrm{E}}$, received by the sample during its geological or archaeological history. The dose, its unit is Gray (Gy), is a function of the natural dose rate, $\mathrm{d}_{\mathrm{a}}$, to which the sample was exposed (in Gy/a), and exposure time, $\mathrm{T}$ (in years). The age of a sample is derived from:

$$
\mathrm{D}_{\mathrm{E}}=\int_{0}^{\mathrm{T}} \mathrm{d}_{\mathrm{a}}(\mathrm{t}) \cdot \mathrm{dt}
$$

The calculation of an ESR age needs the separate determination of the palaeodose and the annual dose rate (for details see Ikeya, 1993). The latter is calculated from measurements of the concentrations of radioactive elements in the sample and the sediment in its immediate environment (though laboratory analyses or in-situ using gamma-ray spectrometry or TL dosimeters) and by estimation of the cosmic rays dose (Prescott \& Hutton, 1988, 1994). The palaeodose is obtained by the additive dose method: several aliquots of the sample are irradiated in the laboratory with a calibrated gamma source (e.g. ${ }^{60} \mathrm{Co}$ or $\left.{ }^{137} \mathrm{Cs}\right)$ and the ESR intensity is plotted versus the added doses. The extrapolation of this dose response curve to the zero intensity gives the gamma equivalent dose $\left(D_{E}\right.$ value $)$ of the sample. The additive dose methods is normally straightforward when applied on tooth enamel (e.g., Grün, 2000, 2006). However, in a preliminary study on teeth from Dmanisi (Garcia, 2004), it was found that the $\mathrm{D}_{\mathrm{E}}$ values were strongly dependent on the weighting of the data points (for more information on ESR fitting procedures, see Grün \& Brumby, 1994).

ESR dating method was applied on various types of material, including speleothem carbonates, corals, mollusc shells, bones, tooth enamel or quartz extracted from sediments or heated pebbles. Amongst them, tooth enamel and bleached sedimentary quartz are particularly interesting for geochronological purposes.

\section{ESR dating of tooth enamel}

Tooth enamel consists almost entirely of hydroxyapatite and changes relatively little during the fossilization processes in comparison with bones (Grün \& Schwarcz, 1987). However, the different dental tissues (enamel, dentine and cement) incorporate uranium during geological times and it is essential to describe the evolution of the uranium content of each tissue with time in order to calculate dose rates and ESR ages.

Several mathematical models have been proposed to calculate ESR ages for tooth enamel. The early uptake (EU) model of Bischoff \& Rosenbauer (1981) proposes that the uranium is quickly incorporated in the dental tissue after the sample's burial. In contrast, the linear uptake (LU) model of Ikeya (1982) assumes regular and continuing uranium incorporation into the sample over time.

A model combining ESR and U-series data (US-ESR model) was later proposed by Grün et al. (1988). It allows the calculation of a specific U-uptake parameter ( $p$-value) for each dental tissue of a same tooth. In this model, the uranium content $\mathrm{U}(\mathrm{t})$ of the considered tissue at time $t$ can be expressed as:

$$
\mathrm{U}(\mathrm{t})=\mathrm{U}_{0}(\mathrm{t} / \mathrm{T})^{\mathrm{p}+1}
$$

where $\mathrm{U}_{0}$ is the measured uranium content and $\mathrm{T}$ the age of the sample.

\section{ESR dating of sunlight bleached quartz}

Quartz is a ubiquitous mineral and its dating is very interesting for geologists and archaeologists, because it represents often the only one suitable material for geochronological studies. However, when quartz grains are extracted from sedimentary deposits, it is not the formation of the mineral that it is dated, but a event that led to a total or partial zeroing of the ESR signal (Yokoyama et al., 1985). This bleaching may be related to a heating event or to sunlight exposure during the transportation phase before the deposition of the sediment.

The Al-centre of quartz is sensitive to sunlight, but it can be only partially bleached. Its geochronological use requires the determination of the ESR intensity corresponding to the maximal bleaching of the sample (for details see Voinchet et al., 2004). The $\mathrm{D}_{\mathrm{E}}$-value is then determined from the additive dose response curve and extrapolation to this maximum bleaching level (fig. 1). The Ti-centre can be completely bleached by sunlight, but seems less stable that the Al-centre and its use seems be restricted to late Middle Pleistocene or Upper Pleistocene samples (Voinchet et al., 2004).

Based on the same principles, luminescence methods (TL and OSL) allow dating of sunlight bleached sediments (Aitken, 1985, 1998). Luminescence analysis can be carried out on single aliquots or even single grains, while ESR is considerably less sensitive, requiring generally multi-aliquot or multi-grain approaches. New developments, however, indicate that ESR may also be applicable on smaller samples (Beerten et al., 2003). However, the chronological range of luminescence methods is often restricted to the last $300 \mathrm{ka}$ (excepted, perhaps for red-TL (Fattahi $\&$ Stokes, 2000, 2005) and newly developed recuperation OSL, Wang et al., 2006) while ESR permits, in 


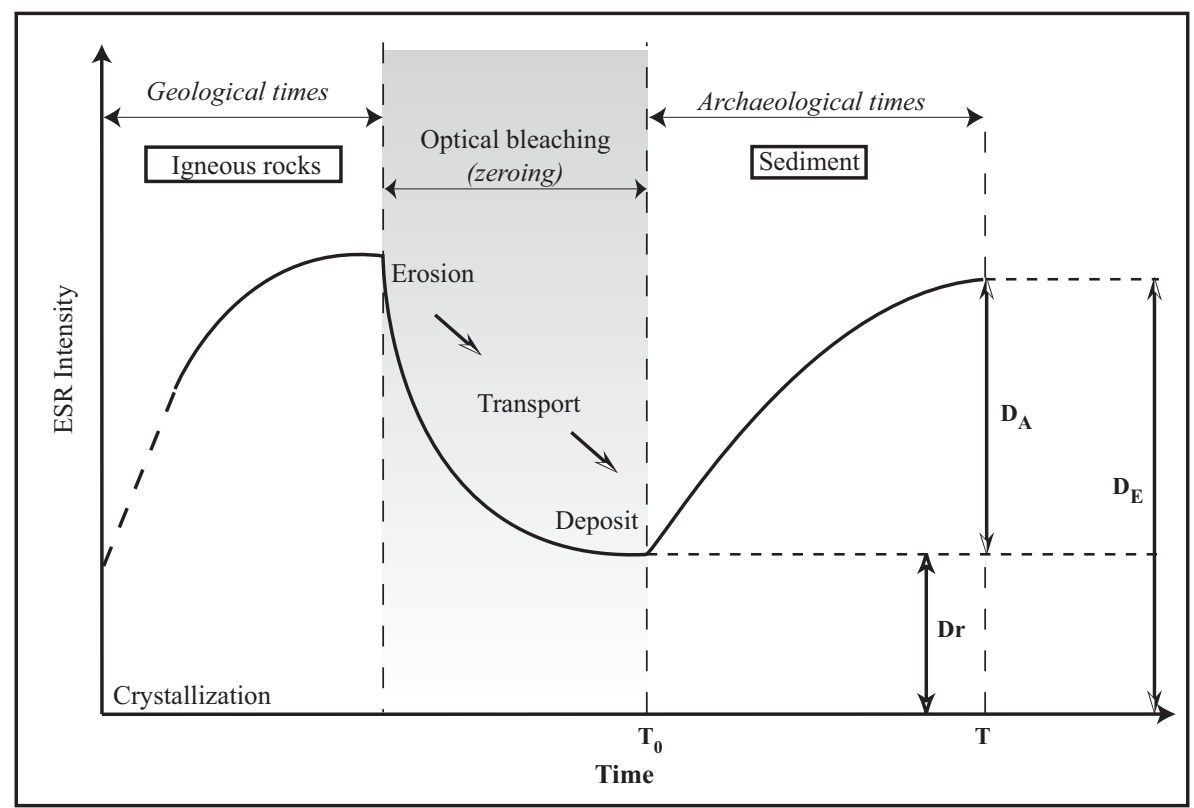

Fig. 1: Evolution of the Aluminium-centre ESR intensity along the geological history of a quartz grain.

Fig. 1 : Evolution de l'intensité ESR du centre aluminium au cours de l'histoire géologique d'un grain de quartz.

theory, the dating of older samples (Voinchet et al., 2004; Despriée et al., 2004; Bahain et al., 2007).

\section{3 - APPLICATION OF THE ESR METHOD TO THE DATING OF SOME EUROPEAN ARCHAEOLOGICAL AND GEOLOGICAL SITES OF LATE LOWER PLEISTOCENE OR EARLY MIDDLE PLEISTOCENE AGES}

Until recently, the dating of the presence of the first human populations in Europe has been a controversial issue, which has split the scientific community because of the poor and sometimes doubtful archaeological record (Roebroeks \& Van Kolfschoten, 1994; Roebroeks, 2001). The recent discoveries of human remains at Atapuerca Gran Dolina, Spain (Carbonell et al., 1995) and at Campo Grande di Ceprano, Italy (Ascenzi et al., 1996), both dated by palaeomagnetism to the Late Lower Pleistocene, seem to have demonstrated the great antiquity of such settlements. Moreover, the discovery of several human remains (including skulls and mandibles) at Dmanisi, Georgia, suggests the presence of humans at the gates of Europe at about 1.8 Ma ago (Gabunia et al., 2000). These human remains, assigned to Homo ergaster, were found in volcanic ashes and fluvio-lacustrine sands lying directly on a basalt flow previously dated to about $1.85 \mathrm{Ma}$. The overlaying volcanic ash level was dated by $\mathrm{Ar} / \mathrm{Ar}$ method to $1.81 \pm$ $0.03 \mathrm{Ma}$ (Lumley et al., 2002).

The discovery of the Dmanisi palaeoanthropological remains has led to an acceptance of the early human presence in Europe and though it the revalorization of rich archaeological sites, essentially located in the Mediterranean area, such as Fuente Nueva III, Barranco Leon (Orce, Spain), Elefante (Atapuerca, Spain), Vallonnet Cave (Roquebrune-cap-Martin,
France) or Monte Poggiolo (Forli, Italy) (fig. 2). The dating of such sites is crucial for the establishment of the chronological framework of the human settlements of Europe and the ESR method seems to be appropriate to participate to this approach. That is the reason why our laboratory has been engaged for more than 20 years in systematically applying the ESR method on teeth and sediments recovered from such ancient sites. A summary of the main obtained results follows.

\section{Atapuerca Gran Dolina TD6 (Spain)}

The archaeological site of Atapuerca Gran Dolina is located in northern Spain, close to the city of Burgos, into the karstic system of the Sierra of Atapuerca (Carbonell et al., 1995). The infill consists of a 18mthick stratigraphical sequence, subdivided into 11 layers, indexed from TD-1 at the bottom to TD-11 at the top (fig. 3). Layer TD-6 is located about $1 \mathrm{~m}$ under the Brunhes-Matuyama palaeomagnetic boundary (Pares et al., 1995) and contained numerous human remains, which present the most ancient palaeoanthropological fossils known in Europe. These fossils have been attributed to a new human species, Homo antecessor, a possible common ancestor of modern humans and Neandertals (Bermudez de Castro et al., 1997). The human remains were discovered in association with primitive lithic tools (Mode 1-Early Palaeolithic, Carbonell et al., 1999) and a rich late Lower Pleistocene fauna (Garcia \& Arsuaga, 1999; Van der Made, 1999; Cuenca-Bescós et al., 1999).

During the ESR study of the Gran Dolina site (Falguères et al., 1999), three teeth from TD6 layer, constrained by magnetostratigraphy to more than 780 ka (Cande \& Kent, 1995), have been analysed (fig. 3). The combination of the ESR data and of the magnetostratigraphical results indicates that the age of the TD6 level is between 780 and $857 \mathrm{ka}$ (2 sigma error 


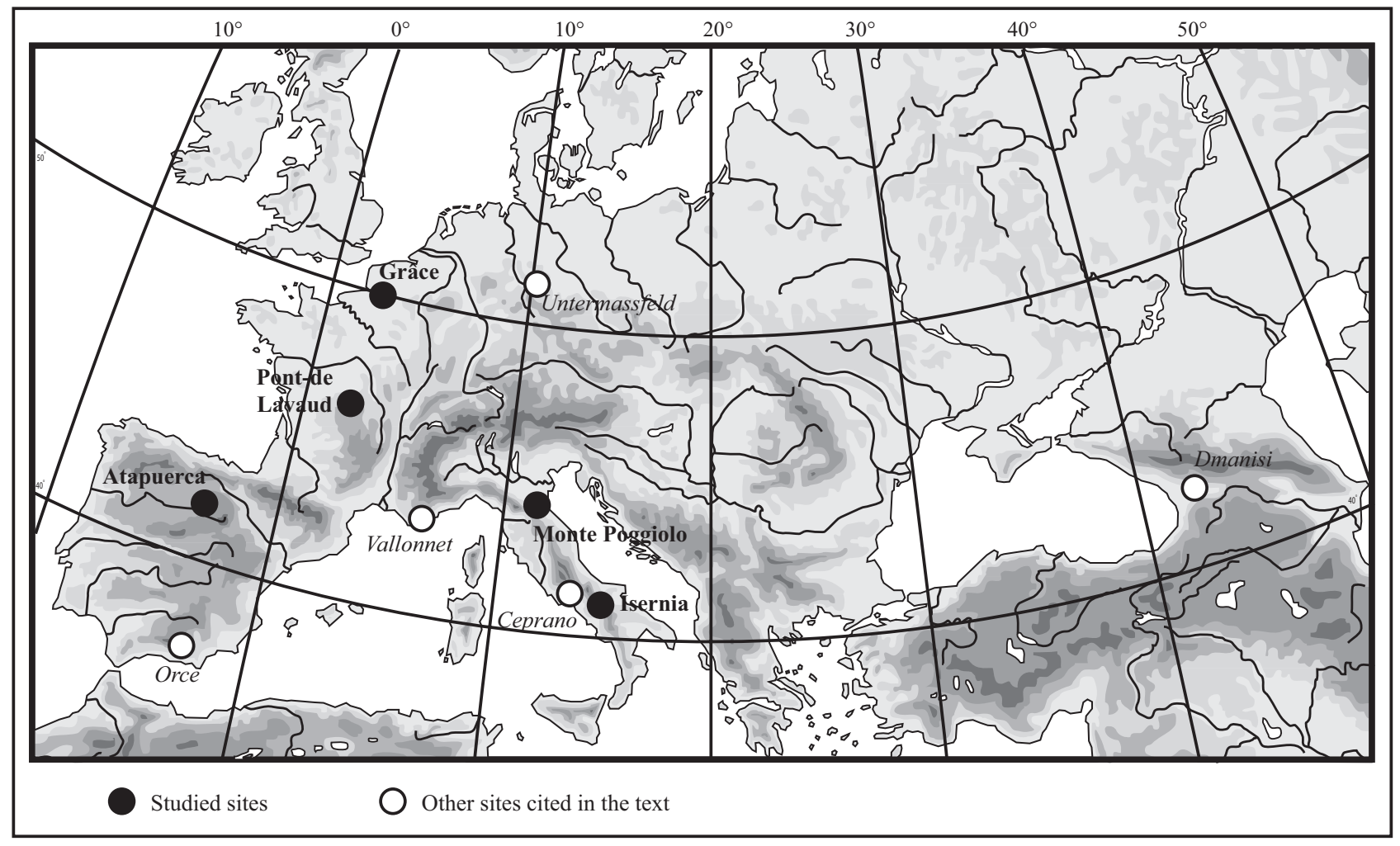

Fig. 2: Geographical location of the studied sites.

Fig. 2 : Localisation géographique des sites étudiés.

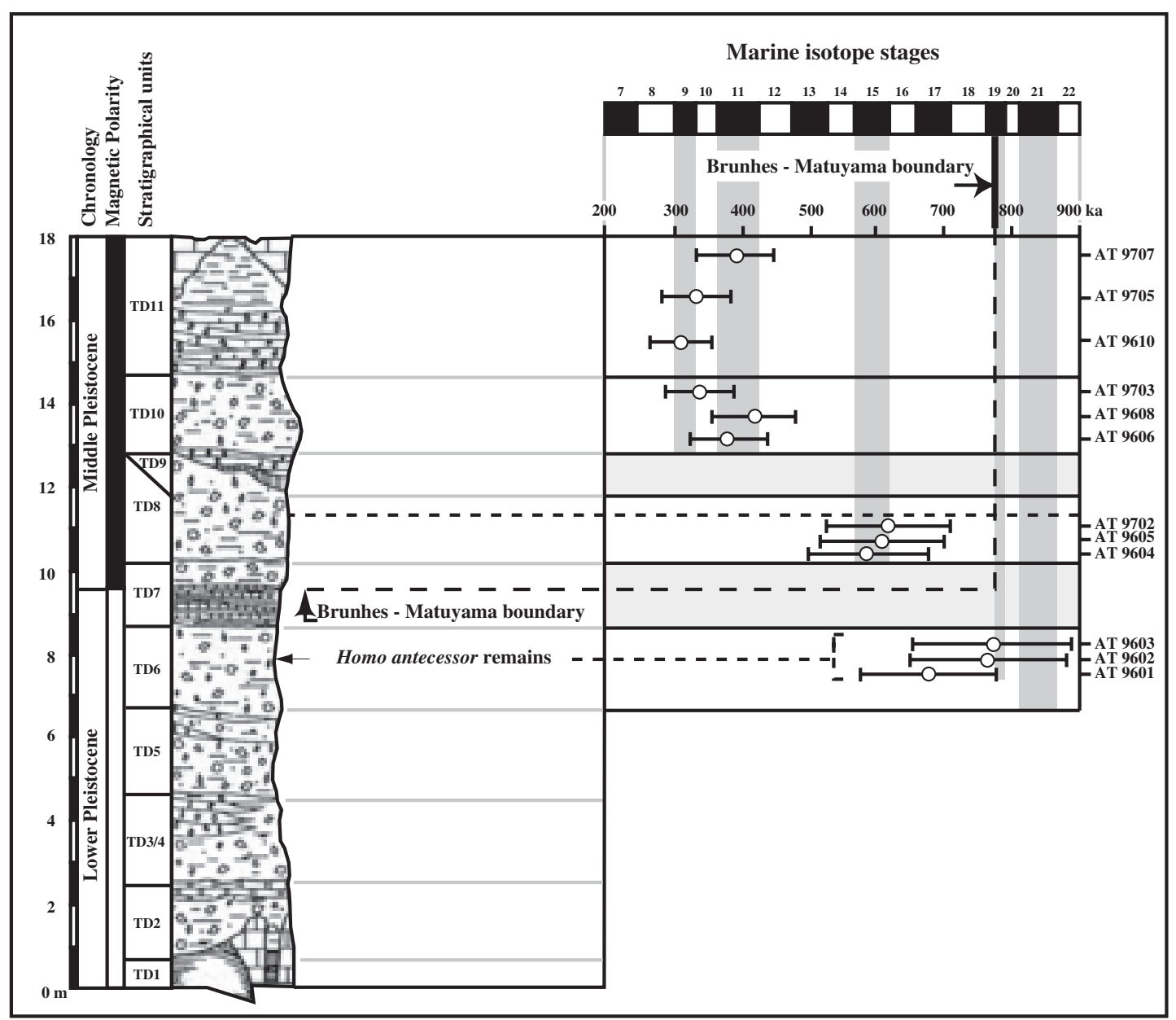

Fig. 3: ESR/U-series ages obtained on teeth recovered from the Atapuerca Gran Dolina Site, Spain (after Falguères et al., 1999). Fig. 3 : Ages ESR/U-Th obtenus sur des dents provenant du site d'Atapuerca Gran Dolina en Espagne (d'après Falguères et al., 1999). 
on the mean age) (Falguères et al., 1999). In addition, palaeoenvironnemental data indicated an interglacial period, which permits to restrict the age to TD-6 to the marine isotopic stage (MIS) 21 or to the first part of MIS 19.

\section{Ca’ Belvedere di Monte Poggiolo (Italy)}

On the southern side of the Po Valley, in Romagna Province (northern Italy), the first slopes of the Apennine Chain are skirted by a system of hills constituted by marine and deltaic sediments of PlioPleistocene age. During the 1980s, numerous Early Palaeolithic artefacts were recovered at several sites. One of these localities, Ca' Belvedere di Monte Poggiolo, was excavated and has delivered thousands of artefacts discovered mainly in deltaic azoic deposits (Peretto, 1992; Peretto et al., 1998).

In the 1990s, chronostratigraphical studies were performed both by magnetostratigraphy (Gagnepain, 1996; Gagnepain et al., 1992, 1998) and ESR dating on quartz (Yokoyama et al., 1992; Gagnepain et al., 1998). Sediments were sampled on different localities of Romagna, characterized by marine or shoreline deposits (Monte Vescovado, Monte Oriolo, San Biagio) or by deltaic or palustrine formations ( $\mathrm{Ca}$ ' Belvedere, $\mathrm{Ca}$ ' del Monte). The ages range is between $700 \mathrm{ka}$ and $1.4 \mathrm{Ma}$ (fig. 4). They are in agreement with palaeomagnetism data, which indicated a reversal polarity for most of the sediments. The set of results permits to date these formations and the associated archaeological sites to the Lower Pleistocene and place these localities amongst the oldest Palaeolithic sites of Italy.

\section{Grâce Autoroute (France)}

Near the city of Amiens, northern France, the Somme Valley shows in its middle part a stepped fluvial terraces system (Antoine, 1994), which contains a range of important Palaeolithic sites (see Tuffreau \& Antoine, 1995). Numerous ESR dates, but also
U-series and magnetostratigraphy studies, were carried out on materials collected from several of the ten fluvial sheets (Laurent et al., 1998; Antoine et al., 2000; Bahain et al., 2007). The results permitted the establishment of a coherent chronostratigraphical framework for the fluvial evolution of the valley during the Pleistocene along with the associated human occupations. The age of each alluvial formation is constrained by the loess-palaeosol successions, which were observed in the slope-deposits sequence covering the terraces and assigned to a cyclic glacial-interglacial pattern (Antoine, 1994).

Amongst the geochronological data obtained on the whole Somme system (Antoine et al., 2000; Bahain et al., 2007), ESR and ESR/U-series data have been obtained on several sediments and a tooth from the oldest fluvial level (Formation X, 55m above the modern valley bedrock). The Grâce-Autoroute terrace, which was recently discovered during highway construction. The ages (fig. 5) range between $950 \mathrm{ka}$ and $1.1 \mathrm{Ma}$, in good agreement with magnetostratigraphical data as well as palaeontological evidence, which indicated the occurrence of the Jaramillo event in the fluvial deposits of the Grâce-Autoroute terrace (Hedley, pers. comm.) and the Brunhes-Matuyama boundary in the underlying fluvial terrace level (Formation IX, $50 \mathrm{~m}$ above the modern valley bedrock; Bourdier et al., 1974).

\section{Pont-de-Lavaud (France)}

The Creuse Valley, in the central part of France, also displays a stepped terraces-system in which Palaeolithic remains are associated with fluvial deposits, but the local geological record is further complicated by recent tectonic events and by the nature of the bedrock (Despriée et al., 2004). Near the town of EguzonChantôme, the basement consists of igneous and metamorphic rocks, eroded by more than $140 \mathrm{~m}$ by the modern valley. In this area, five fossil alluvial formations, indexed from A to E from the most recent to the oldest, were described by Despriée et al. (2004).

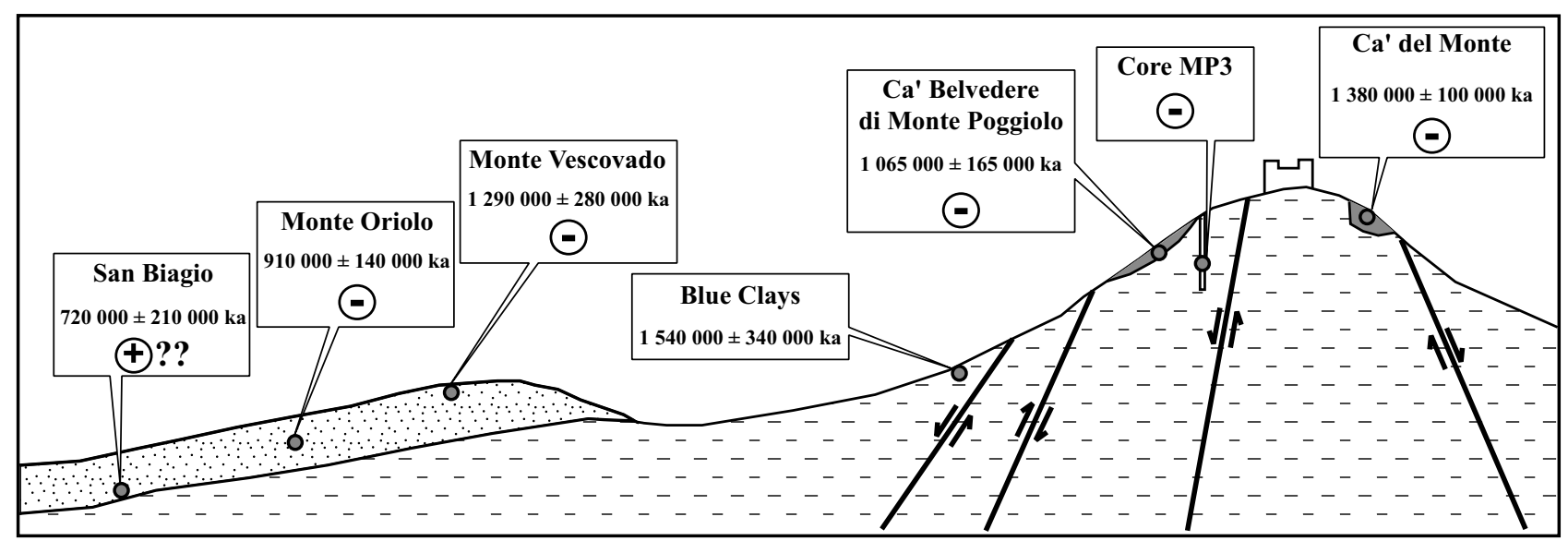

Fig. 4: ESR ages obtained on sediments and carried out from various geological sites of the Forlì area, Italy, and from the archaeological site of Ca' Belvedere di Monte Poggiolo (after Peretto et al., 1998).

Fig. 4 : Ages ESR obtenus sur des sédiments prélevés sur différents sites de la région de Forli en Italie et sur le site archéologique de Ca' Belvedere di Monte Poggiolo (d'après Peretto et al., 1998). 


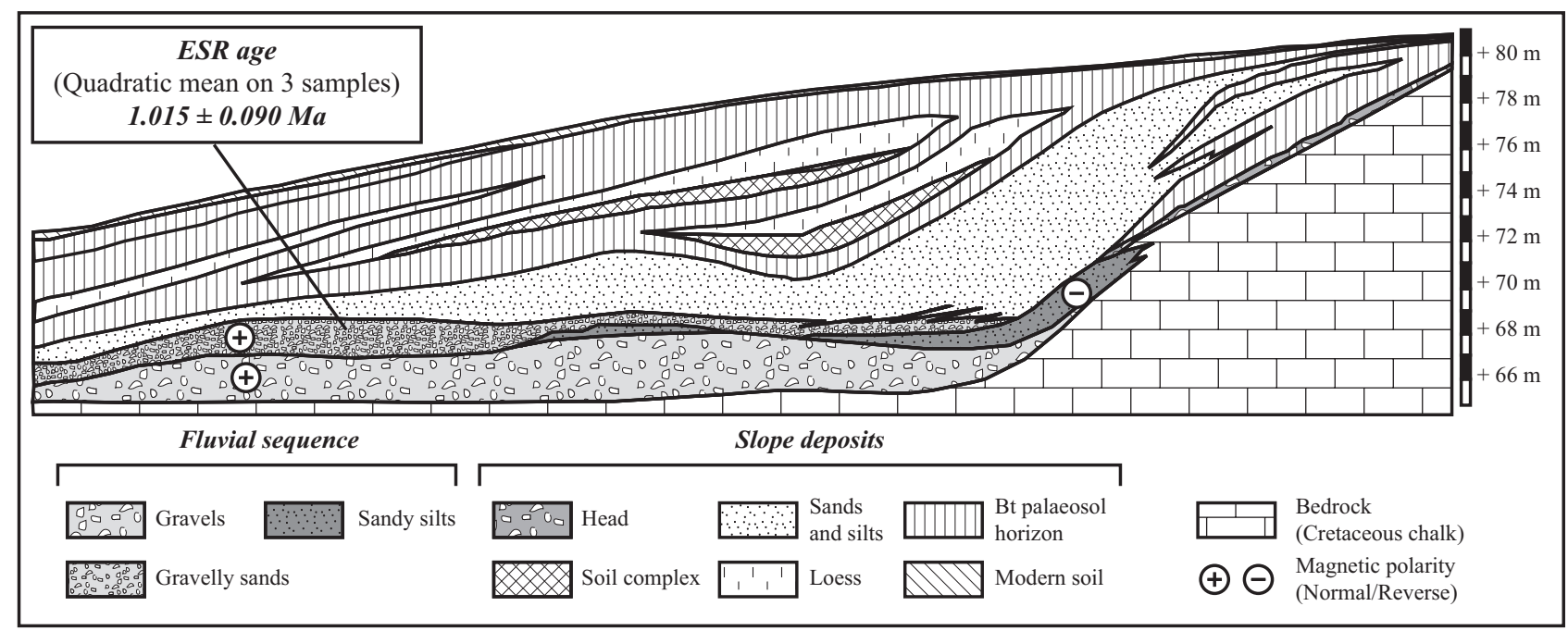

Fig. 5: ESR ages obtained on sediments and ESR/U-series age derived from a bovid tooth sampled in the fluvial deposits of the Grâce-Autoroute Terrace, Somme Valley, France (from a geological section by courtesy of P. Antoine).

Fig. 5 : Ages ESR obtenus sur des sédiments et âge ESR/U-Th obtenu sur une dent provenant des dépôts fluviatiles de la terrasse de Grâce-Autoroute, dans la vallée de la Somme en France (réalisé à partir d'une coupe géologique fournie par P. Antoine).

An important Early Palaeolithic site, Pont-deLavaud, was discovered into the alluvial deposits of Formation D, $90 \mathrm{~m}$ above the modern valley bedrock, and has delivered an abundant archaic lithic industry (Despriée \& Gageonnet, 2003). Since 1996, systematic ESR analyses were carried out on bleached sedimentary quartz sampled from the different alluvial sheets. In association with geological investigations, a geochronological framework for this azoic area could be established (Voinchet, 2002; Falguères et al., 2002; Voinchet et al., 2004). Amongst them, ten samples carried out from different remnants of the Formation D indicated an age of between 1.0 and 1.2 Ma for this alluvial formation and the associated archaeological layers (fig. 6; Despriée et al., 2006).

\section{Isernia La Pineta (Italy)}

The Lower Palaeolithic site of Isernia la Pineta, in Molise, was accidentally discovered in 1978 during highway construction works. During the 1980 s, it was considered to be one of the earliest human occupation sites in Italy during the late Lower Pleistocene, on the basis of $\mathrm{K}-\mathrm{Ar}$ and ${ }^{39} \mathrm{Ar}-{ }^{40} \mathrm{Ar}$ ages as well as magnetostratigraphical and palaeontological data (Coltorti et al., 1982; Peretto et al., 1983). The first ESR and U-series analyses were performed on Isernia samples at the end of the 1980s, but the obtained results indicated an age for the locality considerably younger than proposed from magnetostratigraphical and geochronological data (Bahain et al., 1992).

During the 1990s, new magnetostratigraphical analyses indicated that the whole archaeological fluviolacustrine sequence showed a normal magnetic polarity and was therefore deposited during the Brunhes Chron, i.e., in the Middle Pleistocene (Gagnepain, 1996). More recently, ${ }^{39} \mathrm{Ar}-{ }^{40} \mathrm{Ar}$ data have allowed the dating of the main archaeological level (t3a) to $606 \pm 2 \mathrm{ka}$, thus confirming the Middle Pleistocene age of the locality (Coltorti et al., 2005).

New ESR/U-series analyses were carried out, indicating late uranium uptake in all the dental tissues and great differences between the ages obtained on rhinoceros teeth, all of which strongly underestimated the independent dating results (the weighted mean of the ESR ages, $345 \pm 67 \mathrm{ka}$, calculated from five teeth). A bovid tooth, with an ESR age of $560 \pm 84 \mathrm{ka}$, is in relatively good agreement with ${ }^{39} \mathrm{Ar}-{ }^{40} \mathrm{Ar}$ data. (fig. 7) (Falguères et al., 2007).

A recent change of the dosimetric environment of the teeth, during MIS 5 or even during the Holocene, was initially suspected. The archaeological layer consists of a very high number of bones and a relatively recent influx of uranium may have increased not only the internal dose rate parameters, but also the environmental ones. This would have a strong impact on the age calculations. However, such a change would also have affected the bovid tooth, which was recovered at few centimetres away from one of the rhinoceros teeth. It is interesting to note that U-concentrations and U-series isotopic ratios in the dental tissues of the bovid and rhinoceros are virtually the same within error, the difference is that the bovid tooth has a two times higher $\mathrm{D}_{\mathrm{E}}$ value (Falguères et al., 2007). This may point perhaps to a "taxonomic" effect, caused by micro-structural differences in the enamel between bovids and rhinoceroses. Additional analyses on bovid teeth are in progress to confirm this.

\section{4 - DISCUSSION AND PERSPECTIVES}

Since the 1980s, ESR and ESR/U-series dating methods have been applied on palaeontological and geological materials recovered from several late Lower 
Relative

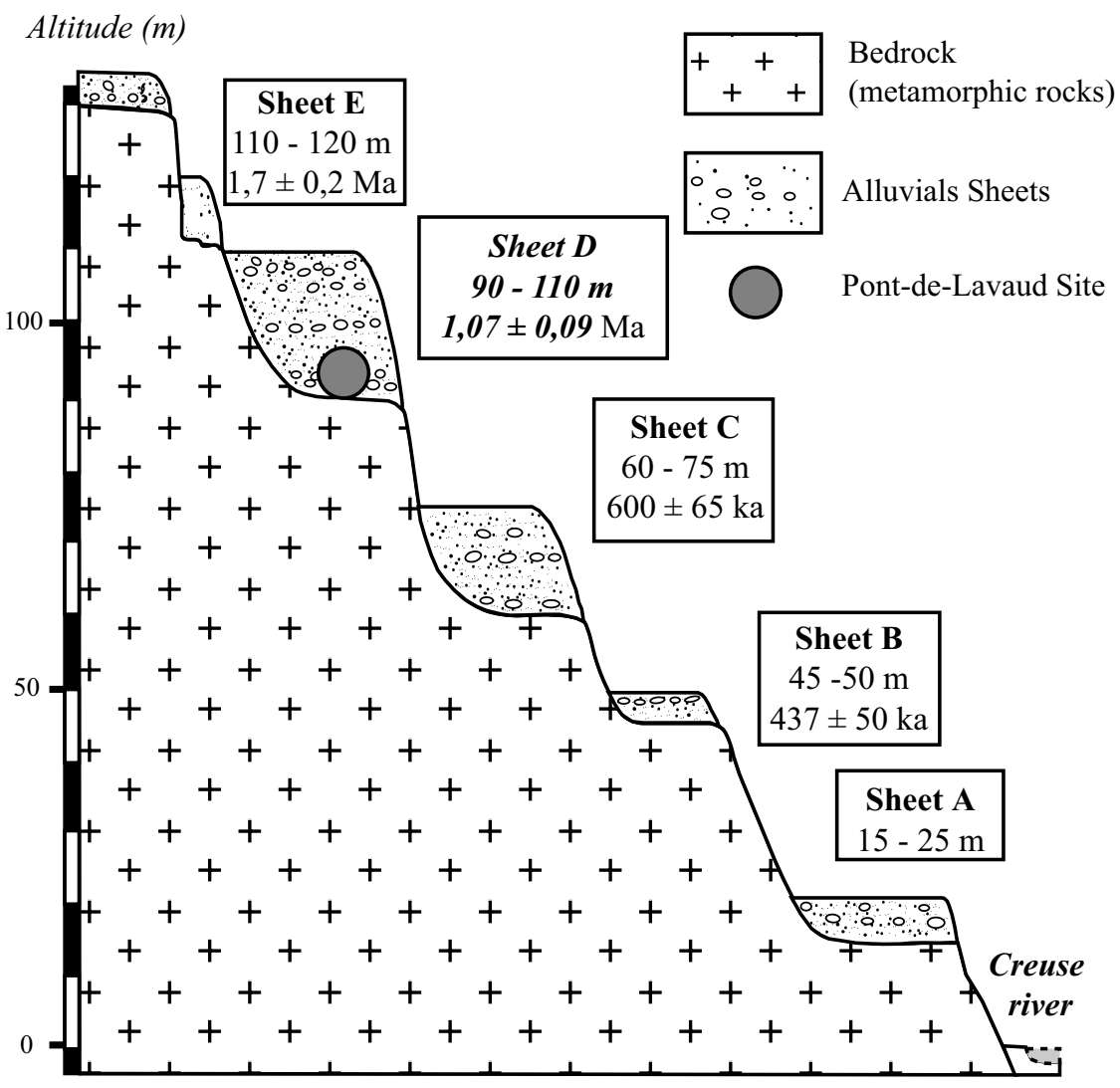

Fig. 6: ESR ages obtained on sediments carried out from the fluvial deposits of the Creuse River terrace system, France, and from the archaeological site of Pont-de-Lavaud (after Falguères et al., 2002).

Fig. 6 : Ages ESR obtenus sur des sédiments prélevés dans les dépôts fluviatiles du système de terrasses de la Creuse et du site archéologique de Pont-deLavaud. (d'après Falguères et al., 2002).

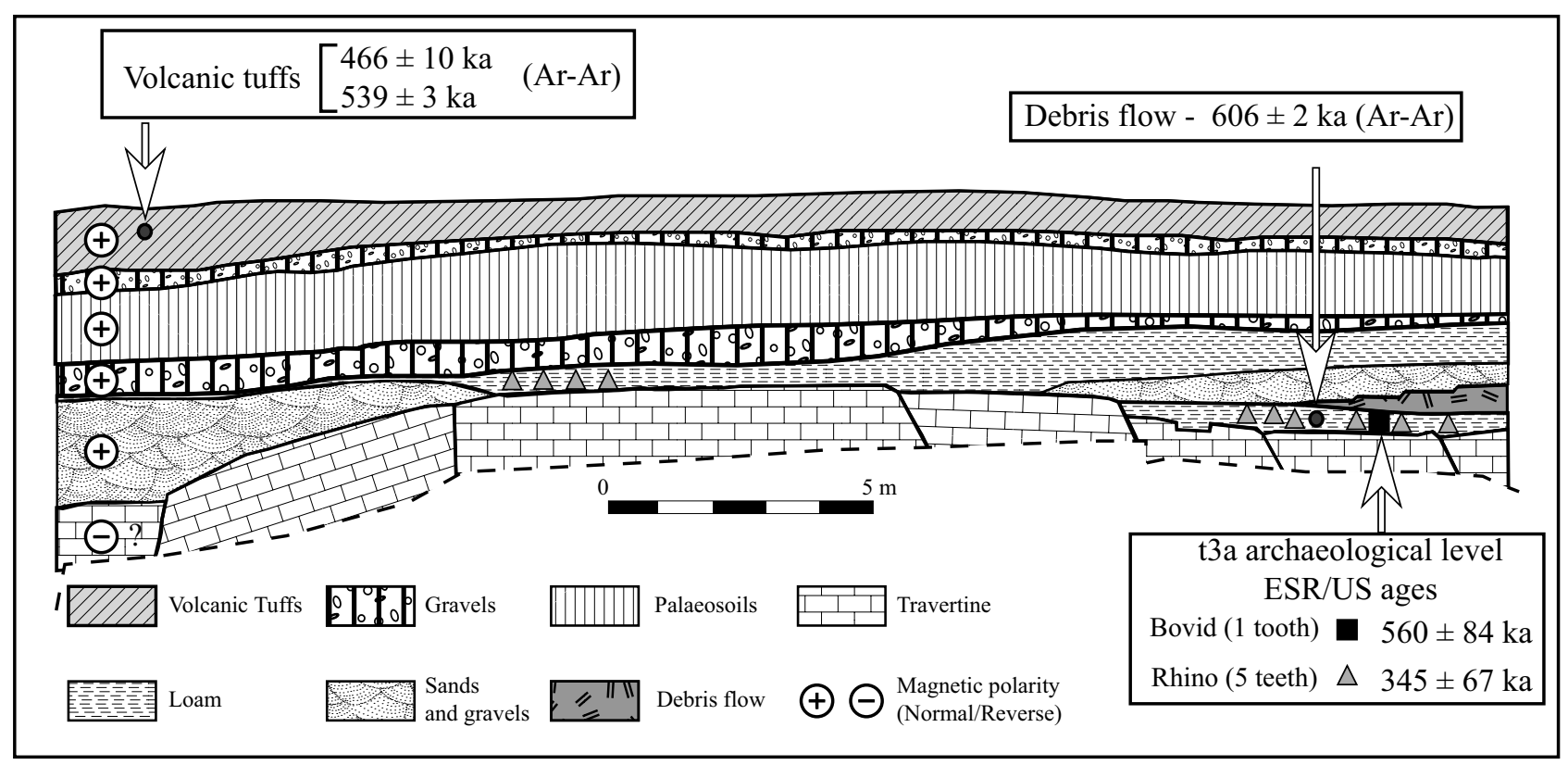

Fig. 7: ESR/U-series ages obtained on teeth recovered from the Isernia la Pineta Site, Italy (after Perreto et al., 1983).

Fig. 7 : Ages ESR/U-Th obtenus sur des dents provenant du site d'Isernia la Pineta en Italie (d'après Peretto et al., 1983). 


\begin{tabular}{|c|c|c|c|c|c|}
\hline Site & Unit & Samples & \begin{tabular}{|c|} 
ESR /U-series \\
or ESR ages (ka)
\end{tabular} & Independante age estimate & references \\
\hline $\begin{array}{c}\text { Atapuerca } \\
\text { Gran Dolina }\end{array}$ & TD6 & 3 teeth & $731 \pm 63$ & $\begin{array}{c}\text { Reversal magnetic polarity } \Rightarrow \\
\text { Below Brunhes/Matuyama } \\
\text { boundary } \\
>780 \mathrm{ka} \text { (palaeomagnetism) }\end{array}$ & $\begin{array}{l}\text { Parés et al. (1995) } \\
\text { Falguères et al. (1999) }\end{array}$ \\
\hline $\begin{array}{l}\text { Ca’ Belvedere } \\
\text { di Monte } \\
\text { Poggiolo }\end{array}$ & $\begin{array}{c}\text { Layers } \\
111-118\end{array}$ & 3 sediments & $1065 \pm 165$ & $\begin{array}{c}\text { Reversal magnetic polarity } \Rightarrow \\
\text { Below Brunhes/Matuyama } \\
\text { boundary } \\
\text { Between } 780 \text { ka and } 990 \text { ka or } \\
\text { older than } 1.07 \mathrm{Ma} \\
\text { (palaeomagnetism) }\end{array}$ & $\begin{array}{l}\text { Gagnepain et al. (1992) } \\
\text { Gagnepain et al. (1998) }\end{array}$ \\
\hline & & 1 tooth & $974 \pm 146$ & Location in the fluvial system & \\
\hline Grâce-Autoroute & Fluvial silts & 2 sediments & $1036 \pm 112$ & $\begin{array}{c}\text { (Sheet } X-+55 \mathrm{~m} \\
\text { above the modern bedrock) } \\
\text { Normal magnetic polarity } \\
\text { below reversal polarity } \Rightarrow \\
\text { Jaramillo Subchron } \\
\text { Between } 0.99 \text { and } 1.07 \mathrm{Ma} \\
\text { (palaeomagnetism) }\end{array}$ & $\begin{array}{l}\text { Antoine et al. }(2000) \\
\text { Hedley (pers. comm.) }\end{array}$ \\
\hline Pont-de-Lavaud & Sheet D & 10 sediments & $1071 \pm 90$ & $\begin{array}{l}\text { Location in the fluvial system } \\
\text { (Sheet XI }-+90 \mathrm{~m} \\
\text { above the modern bedrock) }\end{array}$ & $\begin{array}{l}\text { Voinchet et al. (2004) } \\
\text { Despriée } \text { et al. (2006) }\end{array}$ \\
\hline \multirow{2}{*}{ Isernia la Pineta } & \multirow[b]{2}{*}{$\mathrm{t} 3 \mathrm{a}$} & 1 bovid tooth & $560 \pm 84$ & \multirow{2}{*}{$\begin{array}{l}606 \pm 2 \mathrm{ka}\left({ }^{39} \mathrm{Ar}-{ }^{40} \mathrm{Ar}\right) \\
\text { Normal magnetic polarity } \\
\Rightarrow \text { Brunhes Chron }\end{array}$} & \multirow{2}{*}{$\begin{array}{l}\text { Coltorti et al. (2005) } \\
\text { Falguères et al. (2007) }\end{array}$} \\
\hline & & 5 rhinoceros teeth & $345 \pm 67$ & & \\
\hline
\end{tabular}

Tab. 1: ESR and ESR/U-series ages obtained on the different Lower Pleistocene and early Middle Pleistocene studied sites and comparison with the available geochronological data.

Tab. 1 : Ages ESR et ESR/U-Th obtenus sur les différents sites du Pléistocène inférieur et du début de Pléistocène moyen étudiés et comparaison avec les données géochronologiques disponibles.

Pleistocene and early Middle Pleistocene sites in Western Europe. Whenever possible, the reliability of the ESR results were checked against other independent geochronological methods such as ${ }^{39} \mathrm{Ar}-{ }^{40} \mathrm{Ar}$, palaeo- magnetism and biostratigraphy (tab. 1).

ESR/U-series dating of mammal tooth enamel seems to be particularly interesting for Palaeolithic archaeology, because it allows the direct dating of anthropological and palaeontological specimens. The results obtained on the sites of Atapuerca Gran Dolina and Grâce-Autoroute are very promising, but the application of the method at Isernia illustrates the problems and the limits of the method. Palaeontological taxonomy, uranium uptake history and the change of the dose rate conditions during burial and depositional history have an effect on the age calculations. Particularly for older sites, a comparison of ESR ages with independent geochronological data seems generally be preferable to a systematic use of the ESR method without such control.

In that aim, the study of different Lower Pleistocene sites is in progress. An ESR study was particularly undertaken on teeth from the Dmanisi site, Georgia, which is dated by ${ }^{39} \mathrm{Ar}-{ }^{40} \mathrm{Ar}$ of $1.81 \pm 0.03 \mathrm{Ma}$ and has delivered several human skulls, a rich Lower Pleistocene fauna and an abundant lithic material (Garcia, 2004). This study has showed, on the one hand, that the choice of the weighted fitting methods used for the $D_{E}$ determination have an effect on the obtained results and, on the other hand, that the isotopic ${ }^{230} \mathrm{Th} /{ }^{234} \mathrm{U}$ ratios measured on the dental tissues can be considerably greater than the expected values for such an ancient site, leading to enormous recalculated initial uranium contents (and associated internal dose rates) and severe underestimation of the ESR/U-series ages.

Similar work was initiated in Spanish archaeological and palaeontological localities of Atapuerca (karstic localities of Elefante (Parés et al., 2006) and Gran Dolina lower levels) and Orce, Andalousia (fluvio-lacustrine sites of Fuente Nueva III, Barranco Leon and Venta Micena (Turcq et al., 1996; Martinez-Navarro et al., 1997; Oms et al., 2000)), all dated by magnetostratigraphy and biostratigraphy between 0.8 and 1.6 Ma. We hope that in such low uranium context we can obtain a better view of the real possibility of the ESR/U-series method.

In the same way, ESR dating of bleached fluvial quartz could offer the possibility to date numerous azoic early Palaeolithic sites such as Pont-de-Lavaud, but again it seems crucial to apply the method on welldated levels and to compare the results obtained from the Ti and Al ESR quartz centres. Furthermore, the poor sensitivity of the Al-center and the variations of the bleaching rate observed for different sediments from a same alluvial terrace imply that the results have to be treated with caution. Hence, it seems better to 
work on a complete stepped alluvial system than on an isolated fluvial deposit, the former having the advantage of providing stratigraphical control for the sequence of ESR results. Such an approach has been recently applied on several river systems in northern France (Creuse, Yonne, Loir and Somme systems) and has well documented the potential of the method (Voinchet et al., 2004; Despriée et al., 2003, 2004; Bahain et al., 2007) Finally, the application of the ESR method on quartz sediment and of the ESR/U-series method on tooth enamel at the same site, e.g. GrâceAutoroute, was also investigated. The same approach will be applied to materials recovered from the paleontological locality of Untermassfeld, Germany (Kahlke \& Gaudzinski, 2005) and from the archaeological site of Yunxian, China (Li \& Etler, 1992), both placed by biostratigraphy and magnetostratigraphy around the Jaramillo palaeomagnetical event, dated around $1 \mathrm{Ma}$. The results will show whether the application of ESR and ESR/U-series methods can be systematically used for the dating of Lower Pleistocene sites.

\section{ACKNOWLEDGEMENTS}

The ESR and U-series laboratory of the French National Museum of Natural History was initiated in 1988 following an initiative by Henry de Lumley and Yuji Yokoyama. The ESR spectrometer of the French National Museum of Natural History was bought with the financial support of the 'Sesame Île-de-France' program and the present work was essentially financially supported by the National Museum of Natural History and the French National Centre for the Scientific Research through different projects The authors thank all the archaeologists, palaeontologists and geologists which have provided the samples, particularly Pierre Antoine, Juan-Luis Arsuaga, Patrick Auguste, Jose Maria Bermudez de Castro, Eudald Carbonell, Robert Gageonnet and Carlo Peretto. Finally, we will thank the referees Philip Gibbard and Rainer Grün, for their constructive comments and corrections and their help for the redaction of some parts of the manuscript.

\section{REFERENCES}

AITKEN M.J., 1985 - Thermoluminescence dating. Academic press, $359 \mathrm{p}$.

AITKEN M.J., 1998 - An Introduction to Optical Dating. Oxford University Press, $267 \mathrm{p}$.

ANTOINE P., 1994 - The Somme Valley terrace system Northern France; a model of river response to quaternary climatic variations since 800,000 BP. Terra-Nova, 6, 453-464.

ANTOINE P., LAUTRIDOU J.P., \& LAURENT M., 2000 - Longterm fluvial archives in NW France: response of the Seine and Somme Rivers to tectonic movements, climatic variations and sea level changes. Geomorphology, 873, 551-563.

ASCENZI A., BIDDITTU I., CASSOLI P. F., SEGRE A.G., \& SEGRE-NALDINI E., 1996 - A calvarium of late Homo erectus from Ceprano, Italy. Journal of Human Evolution, 31, 409-423.

BAHAIN J.J., FALGUÈRES C., LAURENT M., VOINCHET P., DOLO J.M., ANTOINE P., \& TUFFREAU A., 2007 - ESR chronology of the Somme River Terrace system and first human settlements in Norther n France. Quaternary Geochronology, 2, 356-362

BAHAIN J.J., LAURENT M., FALGUÈRES C., VOINCHET P., FARKH S., \& TISSOUX H., 2002 - Datation par résonance paramagnétique électronique (RPE) des formations fluviatiles pléistocènes et des gisements archéologiques ou paléontologiques associés. Quaternaire, 13, 91-103.
BAHAIN J.J., YOKOYAMA Y., FALGUÈRES C., \& SARCIA M.N., 1992 - ESR dating of tooth enamel: a comparison with K-Ar dating. Quaternary Science reviews, 11, 245-250.

BEERTEN K., PIERREUX D., \& STESMANS A., 2003 - Towards single grain ESR dating of sedimentary quartz: first results. Quaternary Science Reviews, 22, 1329-1334.

BERMUDEZ DE CASTRO J.M., ARSUAGA J.L., CARBONELL E., ROSAS A., MARTINEZ I., \& MOSQUERA M., 1997 - A hominid from the Lower Pleistocene of Atapuerca, Spain: possible ancestor to Neandertals and Modem Humans. Science, 276, 1392-1395

BISCHOFF J.L., \&. ROSENBAUER R.J.V., 1981 - U-series dating of bones and carbonates deposits of the Caune de l'Arago at Tautavel. In H. Lumley de \& et J. Labeyrie (eds.), Datations et analyses isotopiques en Préhistoire - Méthodes et limites. Prétirage, CNRS, Paris, 327-347

BOURDiER F., CHALINE J., MUNAUT A.V., \& PUISSEGUR J.J., 1974 - La très haute nappe alluviale de la Somme. Bulletin de l'Association Française pour l'Etude du Quaternaire, 11, 137-143.

CANDE S.C., \& KENT D.V., 1995 - Revised calibration of the geomagnetic polarity timescale for the Late Cretaceous and Cenozoic. Journal of Geophysical Research, 100, 6093-6095.

CARBONELL E., BERMUDEZ DE CASTRO J.M., ARSUAGA J.L., DIEZ J.C., ROSAS A., CUENCA-BESCOS G., SALA R., MOSQUERA M., \& RODRIGUEZ X.P., 1995 - Lower Pleistocene hominids and artefacts from Atapuerca-TD6 (Spain). Science, 269, 826-830.

CARBONELL E, GARCIA-ANTON M.D, MALLOL C MOSQUERA M., OLLE A., RODRIGUEZ X.P., SAHNOUNI M., SALA R., \& VERGES J.M., 1999 - The TD6 level lithic industry from Gran Dolina, Atapuerca (Burgos, Spain): Production and use. Journal of Human Evolution, 37, 653-693.

COLTORTI M., FERAUD G., MARZOLI A., PERETTO C., TON-THAT T., VOINCHET P., BAHAIN J.J., MINELLI A., \& THUN HOHENSTEIN U., 2005 - New ${ }^{40} \mathrm{Ar} /{ }^{39} \mathrm{Ar}$, stratigraphic and palaeoclimatic data on the Isernia La Pineta Lower Palaeolithic site, Molise, Italy. Quaternary International, 131, 11-22.

COLTORTI M., CREMASCHI M., DELITALA M.C., ESU D., FORNASERI M., McPHERRON A., NICOLETTI M., VAN OTTERLOO R., PERETTO C., SALA P., SCHMIDT V., \& SEVINK J., 1982 - Reversed magnetic polarity at Isernia La Pineta, a new lower Paleolithic site in Central Italy. Nature, 300, 173 176.

CUENCA-BESCOS G., LAPLANA C., \& CANUDO J.I., 1999 Biochronological implications of the Arvicolidae (Rodentia, Mammalia) from the Lower Pleistocene hominid-bearing level of Trinchera Dolina 6 (TD6, Atapuerca, Spain). Journal of Human Evolution, 37, 353-373.

DESPRIÉE J., \& GAGEONNET R., 2003 - La très haute nappe alluviale d'âge pléistocène inférieur de la vallée de la Creuse à Eguzon (Indre) : figures de cryoturbations, habitats préhistoriques et datations absolues. Bulletin de la Société Géologique de France, 174, 383-400.

DESPRIÉE J., GAGEONNET R., VOINCHET P., BAHAIN J.J. FALGUĖRES C., DUVIALARD J., \& VARACHE F., 2004 Pleistocene fluvial systems of the Creuse river (Middle Loire basin - Centre Region - France). Quaternaire, 15, 77-86.

DESPRIÉE J., GAGEONNET R., VOINCHET P., BAHAIN J.J., FALGUERES C., VARACHE F., COURCIMAULT G., \& DOLO J.M., 2006 - Une occupation humaine au Pléistocène inférieur sur la bordure nord du Massif central. C. R. Palevol, 5, 821828.

DESPRIÉE J., VOINCHET P., BAHAIN J.J., FALGUÈRES C. LORAIN J.M., \& DUVIALARD J., 2003 - Les nappes alluviales pléistocènes du Loir dans la région de Vendôme (Loir-et-Cher, France) : contexte morphosédimentaire et chronologie RPE. Quaternaire, 14, 207-218.

FALGUÈRES C., BAHAIN J.J., YOKOYAMA Y., ARSUAGA J.L., BERMUDEZ DE CASTRO J.M., CARBONELL E., BISCHOFF J.L., \& DOLO J.M., 1999 - Earliest Humans in Europe: the age of Atapuerca fossils, Spain. Journal of Human Evolution, 37, 343-352. 
FALGUÈRES C., \& BAHAIN J.J., 2002 - La datation par résonance paramagnétique électronique (RPE). In J.C. Miskovsky (ed), Géologie de la Préhistoire - Méthodes, techniques, applications. Géopré, Perpignan, 1273-1296.

FALGUERES C., VOINCHET P., \& BAHAIN J.J., 2002 - ESR dating as a contributor to the chronology of the earliest humans in Europe. Advances in ESR Applications, 18, 67-76.

FALGUÈRES C., BAHAIN J.J., DOLO J.M., MERCIER N., \& VALLADAS H., 2007 - On the inter est and the limits of using combined ESR/U-series model in the case of very late uranium uptake. Quaternary Geochronology, 2, 403-408.

FATTAHI M., \& STOKES S., 2000 - Extending the time range of luminescence dating using red TL (RTL) from volcanic quartz. $R a$ diation Measurements, 32, 479-485.

FATTAHI M., \& STOKES S., 2005 - Dating unheated quartz using a single aliquot regeneration-dose red thermoluminescence protocol (SAR RTL). Journal of Luminescence, 115, 19-31.

GABUNIA L., VEKUA A., LORDKIPANIDZE D., SWISHER C.C., FERRING R., JUSTUS A., NIORADZE M. TVALCHRELIDZE M., ANTON S.C., BOSINSKI G.J., ORIS O., LUMLEY M.A. de, MAJSURADZE G., \& MOUSKHELISHVILI A., 2000 - Earliest Pleistocene hominid cranial remains from Dmanisi, Republic of Georgia: taxonomy, geological setting and age. Science, 288, 1019-1025.

GAGNEPAIN J., 1996 - Etude magnétostratigraphique de sites du Pléistocène inférieur et moyen des Alpes-Maritimes et d'Italie: Grotte du Vallonnet, Marina Airport, Ca'Belvedere di Monte Poggiolo, Isernia la Pineta, Venosa Loreto. Thèse de doctorat, $\mathrm{Mu}$ séum National d'Histoire Naturelle, Paris, 615 p.

GAGNEPAIN J., HEDLEY I., BAHAIN J.J., \& WAGNER J.J., 1992 - Premiers résultats de l'étude magnétostratigraphique du site de Monte Poggiolo. In C. Peretto (ed.), I primi abitanti della valle padana: Monte Poggiolo nel quadro delle conoscenze europee. Jaca Book, Milano, 255-273

GAGNEPAIN J., LAURENT M., BAHAIN J.J., FALGUÈRES C., HEDLEY I., PERETTO C., WAGNER J.J., \& YOKOYAMA Y., 1998 - Synthèse des données paléomagnétiques et radiochronologiques du site de Ca' Belvedere di Monte Poggiolo (Romagne, Italie) et de son environnement géologique. Actes du XIII Congrès UISPP, Forli, vol. 6, tome II, 877-888

GARCIA N., \& ARSUAGA J.L., 1999 - Carnivores from the Early Pleistocene hominid-bearing Trinchera Dolina 6 (Sierra de Atapuerca, Spain). Journal of Human Evolution, 37, 415-430.

GARCIA T., 2004 - Cadres stratigraphique, magnétostratigraphique et géochronologique des hominidés fossiles du site de Dmanissi en Géorgie. Thèse de doctorat, Muséum National d'Histoire Naturelle, Paris, 233 p

GRÜN R., \& BRUMBY S., 1994 - The assessment of errors in the past radiation doses extrapolated from ESR/TL dose response data. Radiation Measurements, 23, 307-315.

GRÜN R., \& SCHWARCZ H.P., 1987 - Some problems on ESR dating on bones. Ancient TL, 5, 1-9.

GRÜN R., 1989 - Electron spin resonance (ESR) dating. Quaternary International, 1, 65-109.

GRÜN R., 2000 - Methods of dose determination using ESR spectra of tooth enamel. Radiation Measurements, 32, 767-772.

GRÜN R., 2006 - A simple method for the rapid assessment of the qualitative ESR response of fossil samples to laboratory irradiation. Radiation Measurements, 41, 682-689.

GRÜN R., SCHWARCZ H.P., \& CHADAM J.M., 1988 - ESR dating of tooth enamel: coupled correction for U-uptake and U-series disequilibrium. Nuclear Tracks and Radiation Measurements, 14 237-241

IKEYA M., 1982 - A model of linear uranium accumulation for ESR age of Heidelberg (Mauer) and Tautavel bones. Japanese Journal of applied Physics, 22, 763-765.

IKEYA M., 1993 - New applications of electron spin resonance - dating, dosimetry and spectroscopy, World scientific, $500 \mathrm{p}$.
KAHLKE R.D., \& GAUDZINSKI S., 2005 - The blessing of a great flood: differentiation of mortality patterns in the large mammal record of the Lower Pleistocene fluvial site of Untermassfeld (Germany) and its relevance for the interpretation of faunal assemblages from archaeological sites. Journal of Archaeological Science, 32, 1202-1222.

LAURENT M., FALGUÈRES C., BAHAIN J.J., ROUSSEAU L., \& VAN VLIET LANOË B., 1998 - ESR dating of quartz extracted from Quaternary and Neogene sediments: method, potential and limits. Quaternary Geochronology (Quaternary Science Reviews), 17, 1057-1062.

LI T., \& ETLER D.A., 1992 - New Middle Pleistocene hominid crania from Yunxian in China. Nature, 357, 404-407.

LUMLEY de H., LORDKIPANIDZE D., FERAUD G., GARCIA T., PERRENOUD C., FALGUÈRES C., GAGNEPAIN J., SAOS T., \& VOINCHET P., 2002 - Datation par la méthode ${ }^{40} \mathrm{Ar} /{ }^{39} \mathrm{Ar}$ de la couche de cendres volcaniques (couche $\mathrm{VI}$ ) de Dmanissi (Géorgie) qui a livré des restes d'hominidés fossiles de 1,81 Ma. C. R. Palevol, 1, 181-189.

MARTINEZ-NAVARRO B., TURQ A., AGUSTI J., \& OMS O., 1997 - Fuente Nueva-3 (Orce, Granada, Spain) and the first human colonization of Europe. Journal of Human Evolution, 33, 611-620.

OMS O., PARES J.M., MARTINEZ-NAVARRO B., AGUSTI J., TORO I., MARTINEZ-FERNANDEZ G., \& TURQ A., 2000 Early human occupation of Western Europe: Paleomagnetic dates for two paleolithic sites in Spain. PNAS, 97, 10666-10670.

PARÉS J.M., PÉREZ-GONZÁLEZ A., ROSAS A., BENITO A., BERMÚDEZ DE CASTRO J.M., CARBONELL E., \& HUGUET R., 2006 - Matuyama-age lithic tools from the Sima del Elefante site, Atapuerca (northern Spain). Journal of Human Evolution, 50, 163-169.

PARÉS J.M., \& PÉREZ-GONZÁLES A., 1995 - Palaeomagnetic age for Hominid fossils at Atapuerca archaeological site, Spain. Science, 269, 830-832

PERETTO C. (dir), 1992 - I primi abitanti della valle padana: Monte Poggiolo nel quadro delle conoscenze europee. Jaca Book, Milano, $365 \mathrm{p}$

PERETTO C., AMORE F., ANTONIAZZI A., ANTONIAZZI A., BAHAIN J.J., CATTANI L., CAVALLINI E., ESPOSITO P., FALGUÈ RES C., GAGNEPAIN J., HEDLEY I., LAURENT M., LEBRETON V., LONGO L., MILLIKEN S., MONEGATI P., OLLÉ A., PUGLIESE N., RENAULT-MISKOVSKY J., SOZZI M., UNGARO S., VANNUCCI S., VERGES J.M., WAGNER J.J., \& YOKOYAMA Y., 1998 - L'industrie lithique de Ca'Belvedere di Monte Poggiolo: Stratigraphie, matière première, typologie, remontages et traces d'utilisation. L'Anthropologie, 102, 343-465.

PERETTO C., TERZANI C., \& CREMASCHI M. (dir.), 1983 Isernia la Pineta. Un accampamento più antico di 700000 anni. Calderini, Bologne, 125 p.

PRESCOTT J.R., \& HUTTON J.T., 1988 - Cosmic ray and gamma ray dosimetry for TL and ESR. Nuclear Track and radiation Measurements, 14, 223-227.

PRESCOTT J.R., \& HUTTON J.T., 1994 - Cosmic ray contributions to dose rates for luminescence and ESR dating: large depths and long-term time variations. Radiation Measurements, 23, 497 500 .

RINK W.J., 1997 - Electron spin resonance (ESR) dating and ESR applications in Quaternary Science and Archaeometry. Radiation Measurements, 27, 975-1025.

ROEBROEKS W., \& VAN KOLFSCHOTEN T., 1994 - The earliest occupation of Europe: a short chronology. Antiquity, 68, 489503.

ROEBROEKS W., 2001 - Hominid behaviour and the earliest occupation of Europe: an exploration. Journal of Human Evolution, 41, 437-461

TUFFREAU A., \& ANTOINE P., 1995 - The earliest occupation of Europe: continental Northwestern Europe. In W. Roebroeks \& T Van Kolfschoten (eds.), The earliest occupation of Europe. University of Leiden, 147-163.

TURQ A., MARTINEZ-NAVARRO B., PALMQUIST P., ARRIBAS A., AGUSTI J., \& RODRIGUEZ VIDAL J., 1996 Le Plio-Pléistocène de la région d'Orce, province de Grenade, Espagne: bilan et perspectives de recherche. Paléo, 8, 161-204. 
VAN DER MADE J., 1999 - Ungulates from Atapuerca TD6. Journal of Human Evolution, 37, 389-413.

VOINCHET P., 2002 - Datation par résonance paramagnétique électronique (RPE) de quartz blanchis extraits de sédiments fluviatiles pléistocènes : contribution méthodologique et application aux systèmes de la Creuse, du Loir et de l'Yonne. Thèse de doctorat, Muséum National d'Histoire Naturelle, Paris, 234 p.

VOINCHET P., BAHAIN J.J., FALGUÈRES C., LAURENT M., DOLO J.M., DESPRIÉE J., GAGEONNET R., \& CHAUSSE C., 2004 - ESR dating of quartz extracted from Quaternary sediments: Application to fluvial terraces system of Northern France. Quaternaire, 15, 135-141.
WANG X.L., LUA Y.C., \& WINTLE A.G., 2006 - Recuperated OSL dating of fine-grained quartz in Chinese loess. Quaternary Geochronology, 1, 89-100.

YOKOYAMA Y., BAHAIN J.J., FALGUÈRES C., \& GAGNEPAIN J., 1992 - Tentative de datation par la méthode de la résonance de spin électronique (ESR) de sédiments quaternaires de la région de Forli (Italie). In C. Peretto (ed.), I primi abitanti della valle padana: Monte Poggiolo. Jaca Book, Milano, 337-345.

YOKOYAMA Y., FALGUÈRES C., \& QUAEGEBEUR J.P., 1985 - ESR dating of quartz from Quaternary sediments: first attempt. Nuclear Tracks, 10, 921-928. 